\title{
Clinical Study \\ Corneal Endothelial Cell Density and Morphology in Healthy Turkish Eyes
}

\author{
Ceyhun Aricı, Osman Sevki Arslan, and Funda Dikkaya \\ Department of Ophthalmology, Cerrahpasa School of Medicine, Istanbul University, Olgunlar Sokak No. 6/10, \\ Bakirkoy, 34144 Istanbul, Turkey
}

Correspondence should be addressed to Ceyhun Arıc1; ceyhundr@gmail.com

Received 5 October 2013; Accepted 30 December 2013; Published 10 February 2014

Academic Editor: Terri L. Young

Copyright (C) 2014 Ceyhun Arici et al. This is an open access article distributed under the Creative Commons Attribution License, which permits unrestricted use, distribution, and reproduction in any medium, provided the original work is properly cited.

Purpose. To describe the normative values of corneal endothelial cell density, morphology, and central corneal thickness in healthy Turkish eyes. Methods. Specular microscopy was performed in 252 eyes of 126 healthy volunteers (M: F, $42: 84)$. Parameters studied included mean endothelial cell density (MCD), mean cell area (MCA), coefficient of variation (CV) in cell size, percentage of hexagonal cells, and central corneal thickness (CCT). Results. The mean age of volunteers was $44.3 \pm 13.5$ (range, 20 to 70) years. There was a statistically significant decrease in MCD $(P<0.001$; correlation, -0.388$)$ and percentage of hexagonal cells, $(P<$ 0.001 ; correlation, -0.199$)$ with age. There was also a statistically significant increase in MCA $(P<0.001$; correlation, 0.363$)$ with increasing age. There was no statistically significant difference in MCD, MCA, CV in cell size, percentage of hexagonal cells, and CCT between genders and there was also no significant difference in these parameters between fellow eyes of subjects. Conclusions. Normotive data for the endothelium in the Turkish population are reported. Endothelial cell density in the Turkish eyes is less than that described in the Japanese, American, Chinese, and Filipino eyes and higher than that described in Indian, Thai, and Iranian eyes.

\section{Introduction}

Corneal endothelium is essential for the maintenance of the optical transparency of the cornea. Extrinsic factors, such as genetics, race, and age, [1-3] or intrinsic factors, such as trauma, intraocular surgery, ultraviolet radiation, and infection [4-6] are responsible for maintaining the structural and functional integrity of the corneal endothelium.

Clinical observations indicate that an endothelial cell density of 400 to 600 cells $/ \mathrm{mm}^{2}$ is a crucial point at which endothelial decompensation develops [7]. Therefore, ECD is clinically a very important parameter. The metabolic function of these cells is also important because a reduced number of healthy endothelial cells may maintain corneal deturgescence better than a similar number of poorly functioning cells. Because proliferation of human corneal endothelial cells does not continue throughout a person's lifetime, wound healing in human corneal endothelium is mainly accomplished by cell spreading, resulting in increased cellular pleomorphism, and a decrease in the percentage of hexagonal cells with age $[3,7]$.
These parameters, therefore, provide an index of the functional capacity of the endothelium. Normative data regarding endothelial cell density and morphology are thus important because they facilitate assessment of the functional reserve of the endothelium in individual patients.

Due to the existence of variations in endothelial parameters in Indian, Filipino, Iranian, Thai, Chinese, Japanese, and American populations [2, 8-12], knowledge of normative data on the corneal endothelium is important. Data gathered may help in the assessment of the functional endothelial reserve of individuals and may even aid in understanding corneal disease in people of different genders, ages, and ethnic groups.

To the best of our knowledge, such data are not available in the Turkish population, which may differ from those in other races. This prospective study aimed to describe the endothelial cell characteristics and central corneal thickness in healthy Turkish eyes in regard to age and gender and reports the rate of endothelial cell loss with increasing age. 
TABLE 1: Endothelial cell characteristics of the study population in different age groups.

\begin{tabular}{lccccccc}
\hline $\begin{array}{l}\text { Age group } \\
(\mathrm{yr})\end{array}$ & $\begin{array}{c}\text { Age } \\
(\mathrm{yr})\end{array}$ & $\begin{array}{c}\text { Number } \\
(\mathrm{mean} \pm \mathrm{SD})\end{array}$ & $\begin{array}{c}\text { Cell density } \\
\left(\mathrm{cell} / \mathrm{mm}^{2}\right) \\
(\mathrm{mean} \pm \mathrm{SD})\end{array}$ & $\begin{array}{c}\text { Cell area } \\
\left(\mu \mathrm{m}^{2}\right) \\
(\text { mean } \pm \mathrm{SD})\end{array}$ & $\begin{array}{c}\text { CV in cell size } \\
(\%) \\
(\mathrm{mean} \pm \mathrm{SD})\end{array}$ & $\begin{array}{c}\text { Hexagonality } \\
(\%) \\
(\mathrm{mean} \pm \mathrm{SD})\end{array}$ & $\begin{array}{c}\text { CCT } \\
(\mu \mathrm{m}) \\
(\mathrm{mean} \pm \mathrm{SD})\end{array}$ \\
\hline $20-30$ & $23.3 \pm 3.1$ & 42 & $2910.2 \pm 365.9$ & $349.3 \pm 46.5$ & $30.5 \pm 4.0$ & $60.2 \pm 9.4$ & $534.5 \pm 32.6$ \\
$31-40$ & $35.4 \pm 3.2$ & 54 & $2738.3 \pm 389.4$ & $373.0 \pm 56.7$ & $34.9 \pm 5.4$ & $55.9 \pm 9.7$ & $520.1 \pm 31.4$ \\
$41-50$ & $45.2 \pm 2.6$ & 58 & $2682.0 \pm 286.7$ & $377.3 \pm 42.2$ & $36.0 \pm 4.9$ & $52.8 \pm 11.2$ & $530.4 \pm 30.9$ \\
$51-60$ & $52.8 \pm 2.7$ & 56 & $2546.0 \pm 276.4$ & $397.4 \pm 44.1$ & $35.2 \pm 6.0$ & $52.6 \pm 8.9$ & $509.9 \pm 32.6$ \\
$61-70$ & $64.1 \pm 3.6$ & 42 & $2497.6 \pm 331.7$ & $407.2 \pm 53.3$ & $33.6 \pm 3.8$ & $54.4 \pm 8.7$ & $513.1 \pm 30.8$ \\
\hline
\end{tabular}

\section{Patients and Methods}

The study population comprised 126 healthy volunteers randomly selected from the visitors, outpatients, and staff of Istanbul University, Cerrahpasa Medical Faculty, Department of Ophthalmology. Subjects enrolled in the study signed an informed consent form, and the study was in accordance with the tenets of the Helsinki Declaration.

2.1. Selection Criteria. Only healthy volunteers with ages between 20 and 70 years old and with best-corrected visual acuity at least 1,0 (on the Snellen scale) for both eyes, refractive error (in spherical equivalent) within \pm 2.00 diopters, were enrolled in the study. Exclusion criteria included history of intraocular surgery or ocular trauma, corneal opacity, glaucoma, uveitis, evidence of endothelial dystrophy on slit-lamp biomicroscopy, family history of corneal decompensation, use of contact lens, and diabetes mellitus.

2.2. Examinations. Routine ocular examination was performed, and if the participant was found to be suitable for the study, corneal endothelial cell density, morphology and central corneal thickness were examined with noncontact specular microscopy (SP-3000P: Topcon corporation, Tokyo, Japan). A single examiner performed all measurements between 10:00 and 11:30 am. The procedure for specular microscopy was as follows: three images from central cornea were taken and at least 100 contiguous cells and were manually marked by the examiner for analysis by a built-in software program.

Parameters recorded from the system included mean endothelial cell density (MCD) $\left(\right.$ cell $\left./ \mathrm{mm}^{2}\right)$, mean cell area (MCA) $\left(\mu \mathrm{m}^{2}\right)$, coefficient of variation (CV) in cell size, percentage of hexagonal cells, and central corneal thickness (CCT). The CV in cell size (standard deviation divided by the mean cell area) was used as an index of the extent of variation in the cell area (polymegathism). The percentage of hexagonal cells in the analyzed area was used as an index of variation in cell shape (polymorphism).

2.3. Statistical Analysis. Data analysis was performed using SPSS software (version 10.0, SPSS, Inc.). The paired and unpaired $t$-test and Pearson correlation analysis were used. Analysis of variance (ANOVA) and linear regression analysis were used to examine the change in endothelial cell characteristics with age. Data are shown as mean \pm standard deviation. $P$ values less than 0.05 were considered significant.

\section{Results}

The endothelial cell characteristics of 252 eyes of 126 healthy Turkish volunteers were studied. The mean age of the study population was $44.3 \pm 13.5$ years, the range being 20 to 70 years old. There were 42 males and 84 females. The MCD of the population was $2671 \pm 356 \mathrm{cell} / \mathrm{mm}^{2}$ (range, 1834 to $3652 \mathrm{cell} / \mathrm{mm}^{2}$ ). The MCA was $381.2 \pm 51.9 \mu \mathrm{m}^{2}$ (range, 274$545 \mu \mathrm{m}^{2}$ ). The mean CV in cell size was $34.3 \pm 5.3$ (range, 22 to 49), the mean percentage of hexagonal cells was $54.9 \pm 10.0 \%$ (range, 16 to $80 \%$ ), and CCT was $521 \pm 33 \mu \mathrm{m}$ (range, 439 to $621 \mu \mathrm{m}$ ). For the purpose of comparison, subjects were divided by decade of age, and this resulted in 5 subgroups, starting from the third decade (21-30 years; Table 1).

The endothelial cell characteristics did not change significantly between males and females in different age decades $(P>0.05)$ (Table 2$)$. There were also no statistically significant differences in the endothelial cell characteristics between fellow eyes $(P>0.05)$ (Table 3$)$.

The rate of cell loss in each decade of life was studied (Table 4), and, in general, a gradual decrease in the rate of such parameter was noted with advancing age. The highest rate of loss was noted in the 3rd and 5th decade of life in this study population $(5.9 \%$ and $5.1 \%$, resp.).

MCD $(P<0.001$; correlation, -0.388$)$ and percentage of hexagonal cells $(P<0.001$; correlation, -0.199$)$ and CCT $(P<0.001$; correlation, -0.241$)$ decreased significantly with age. In addition, MCA increased significantly $(P<0.001$; correlation, 0.363 ) with increasing age.

Endothelial cell counts in the study population were compared with previously described values for the Japanese, American, Chinese, Filipino, Indian, Thai, and Iranian populations (Table 5).

\section{Discussion}

Several studies have reported the relationship of endothelial cell density and morphology with age, gender, and ethnicity. It is clear that significant differences in corneal endothelial properties do exist among races and ethnic groups [2, 8-12]. Therefore, it is important for populations of different racial 
TABLE 2: Endothelial cell characteristics in female and male.

\begin{tabular}{|c|c|c|c|}
\hline Age group (yr) & $\begin{array}{c}\text { Female } \\
(\text { mean } \pm \mathrm{SD})\end{array}$ & $\begin{array}{c}\text { Male } \\
(\text { mean } \pm S D)\end{array}$ & $P$ value \\
\hline \multicolumn{4}{|l|}{$20-30$} \\
\hline $\begin{array}{l}\text { Cell density } \\
\left(\text { cell } / \mathrm{mm}^{2}\right)\end{array}$ & $2981.9 \pm 396.9$ & $2858.2 \pm 372.8$ & 0.487 \\
\hline Cell area $\left(\mu \mathrm{m}^{2}\right)$ & $341.3 \pm 49.1$ & $355.0 \pm 45.1$ & 0.531 \\
\hline CV in cell size (\%) & $30.8 \pm 4.1$ & $29.5 \pm 3.3$ & 0.461 \\
\hline Hexagonality (\%) & $59.4 \pm 11.2$ & $59.3 \pm 11.1$ & 0.979 \\
\hline $\operatorname{CCT}(\mu \mathrm{m})$ & $540.0 \pm 37.5$ & $521.3 \pm 25.1$ & 0.228 \\
\hline \multicolumn{4}{|l|}{$31-40$} \\
\hline $\begin{array}{l}\text { Cell density } \\
\left(\text { cell } / \mathrm{mm}^{2}\right)\end{array}$ & $2663.1 \pm 329.9$ & $2852.4 \pm 450.4$ & 0.233 \\
\hline Cell area $\left(\mu \mathrm{m}^{2}\right)$ & $381.5 \pm 51.1$ & $359.5 \pm 64.9$ & 0.355 \\
\hline CV in cell size (\%) & $35.1 \pm 5.7$ & $35.7 \pm 5.3$ & 0.784 \\
\hline Hexagonality (\%) & $55.2 \pm 9.5$ & $59.1 \pm 10.5$ & 0.353 \\
\hline $\operatorname{CCT}(\mu \mathrm{m})$ & $522.4 \pm 31.7$ & $514.6 \pm 29.8$ & 0.558 \\
\hline \multicolumn{4}{|l|}{$41-50$} \\
\hline $\begin{array}{l}\text { Cell density } \\
\left(\text { cell } / \mathrm{mm}^{2}\right)\end{array}$ & $2981.9 \pm 396.9$ & $2858.2 \pm 372.8$ & 0.487 \\
\hline Cell area $\left(\mu \mathrm{m}^{2}\right)$ & $383.6 \pm 35.2$ & $372.8 \pm 47.6$ & 0.488 \\
\hline CV in cell size (\%) & $34.7 \pm 4.5$ & $35.8 \pm 4.7$ & 0.522 \\
\hline Hexagonality (\%) & $52.3 \pm 12.2$ & $53.3 \pm 12.8$ & 0.840 \\
\hline $\operatorname{CCT}(\mu \mathrm{m})$ & $536.6 \pm 27.8$ & $523.9 \pm 35.5$ & 0.290 \\
\hline \multicolumn{4}{|l|}{$51-60$} \\
\hline $\begin{array}{l}\text { Cell density } \\
\left(\text { cell } / \mathrm{mm}^{2}\right)\end{array}$ & $2525.4 \pm 279.8$ & $2613.0 \pm 251.9$ & 0.495 \\
\hline Cell area $\left(\mu \mathrm{m}^{2}\right)$ & $401.0 \pm 47.8$ & $385.6 \pm 36.5$ & 0.474 \\
\hline CV in cell size (\%) & $35.1 \pm 6.5$ & $36.4 \pm 4.5$ & 0.646 \\
\hline Hexagonality (\%) & $54.7 \pm 9.0$ & $46.3 \pm 8.5$ & 0.051 \\
\hline $\operatorname{CCT}(\mu \mathrm{m})$ & $511.4 \pm 34.3$ & $511.8 \pm 27.8$ & 0.978 \\
\hline \multicolumn{4}{|l|}{$61-70$} \\
\hline $\begin{array}{l}\text { Cell density } \\
\left(\text { cell } / \mathrm{mm}^{2}\right)\end{array}$ & $2409.4 \pm 271.4$ & $2592.1 \pm 360.5$ & 0.201 \\
\hline Cell area $\left(\mu \mathrm{m}^{2}\right)$ & $420.0 \pm 47.8$ & $392.7 \pm 57.5$ & 0.254 \\
\hline CV in cell size (\%) & $32.4 \pm 4.0$ & $32.8 \pm 5.5$ & 0.831 \\
\hline Hexagonality (\%) & $53.8 \pm 9.2$ & $55.8 \pm 5.9$ & 0.595 \\
\hline $\operatorname{CCT}(\mu \mathrm{m})$ & $519.5 \pm 32.0$ & $507.4 \pm 33.4$ & 0.415 \\
\hline
\end{tabular}

and ethnic backgrounds to establish normative data on which decisions regarding endothelial function can be based. We have developed the first study reporting the corneal endothelial cell characteristics and CCT in Turkish population. Our study showed that in the Turkish population with increasing age there is a general trend toward decreased MCD, increased MCA, increased CV in cell size, and a decreased percentage of hexagonal cells. Although direct comparisons of our results with the results reported by others are limited by the variations in the method used to study the endothelial characteristics, a trend toward lesser cell counts with advancing age is common to these reports after the third decade of life $[2,8,10,11,13]$. Our data revealed lesser cell counts compared with the values reported in Japanese, American, Chinese, and
TABLE 3: Corneal endothelial characteristics in right and left eyes of subjects.

\begin{tabular}{|c|c|c|c|}
\hline Age group (yr) & $\begin{array}{c}\text { Right eye } \\
(\text { mean } \pm S D)\end{array}$ & $\begin{array}{c}\text { Left eye } \\
(\text { mean } \pm S D)\end{array}$ & $P$ value \\
\hline \multicolumn{4}{|l|}{$20-30$} \\
\hline $\begin{array}{l}\text { Cell density } \\
\left(\text { cell } / \mathrm{mm}^{2}\right)\end{array}$ & $2934.8 \pm 383.3$ & $2885.6 \pm 355.4$ & 0.755 \\
\hline Cell area $\left(\mu \mathrm{m}^{2}\right)$ & $346.5 \pm 47.0$ & $352.0 \pm 47.1$ & 0.708 \\
\hline CV in cell size (\%) & $30.3 \pm 3.8$ & $30.8 \pm 4.2$ & 0.684 \\
\hline Hexagonality (\%) & $59.3 \pm 10.9$ & $61.0 \pm 7.9$ & 0.669 \\
\hline $\mathrm{CCT}(\mu \mathrm{m})$ & $532.9 \pm 33.9$ & $536.1 \pm 31.9$ & 0.572 \\
\hline \multicolumn{4}{|l|}{$31-40$} \\
\hline $\begin{array}{l}\text { Cell density } \\
\left(\text { cell } / \mathrm{mm}^{2}\right)\end{array}$ & $2719.2 \pm 371.1$ & $2757.4 \pm 413.0$ & 0.997 \\
\hline Cell area $\left(\mu \mathrm{m}^{2}\right)$ & $375.0 \pm 55.2$ & $371.1 \pm 59.1$ & 0.804 \\
\hline CV in cell size (\%) & $35.3 \pm 5.5$ & $34.5 \pm 5.5$ & 0.580 \\
\hline Hexagonality (\%) & $56.4 \pm 9.8$ & $55.3 \pm 9.7$ & 0.722 \\
\hline $\mathrm{CCT}(\mu \mathrm{m})$ & $520.1 \pm 30.8$ & $520.1 \pm 32.6$ & 0.698 \\
\hline \multicolumn{4}{|l|}{$41-50$} \\
\hline $\begin{array}{l}\text { Cell density } \\
\left(\text { cell } / \mathrm{mm}^{2}\right)\end{array}$ & $2665.7 \pm 274.1$ & $2698.4 \pm 302.7$ & 0.821 \\
\hline Cell area $\left(\mu \mathrm{m}^{2}\right)$ & $379.1 \pm 40.3$ & $375.4 \pm 44.7$ & 0.741 \\
\hline CV in cell size (\%) & $35.1 \pm 4.6$ & $36.9 \pm 5.1$ & 0.172 \\
\hline Hexagonality (\%) & $52.7 \pm 12.2$ & $52.9 \pm 10.3$ & 0.669 \\
\hline $\mathrm{CCT}(\mu \mathrm{m})$ & $531.3 \pm 31.2$ & $529.5 \pm 31.1$ & 0.954 \\
\hline \multicolumn{4}{|l|}{$51-60$} \\
\hline $\begin{array}{l}\text { Cell density } \\
\left(\text { cell } / \mathrm{mm}^{2}\right)\end{array}$ & $2544.2 \pm 272.0$ & $2547.8 \pm 285.7$ & 0.716 \\
\hline Cell area $\left(\mu \mathrm{m}^{2}\right)$ & $397.7 \pm 45.4$ & $397.1 \pm 43.5$ & 0.964 \\
\hline CV in cell size (\%) & $35.4 \pm 6.0$ & $35.0 \pm 6.0$ & 0.814 \\
\hline Hexagonality (\%) & $52.9 \pm 9.4$ & $52.4 \pm 8.6$ & 0.961 \\
\hline $\mathrm{CCT}(\mu \mathrm{m})$ & $511.5 \pm 32.5$ & $508.3 \pm 32.5$ & 0.836 \\
\hline \multicolumn{4}{|l|}{$61-70$} \\
\hline $\begin{array}{l}\text { Cell density } \\
\left(\text { cell } / \mathrm{mm}^{2}\right)\end{array}$ & $2479.0 \pm 313.0$ & $2516.3 \pm 356.3$ & 0.708 \\
\hline Cell area $\left(\mu \mathrm{m}^{2}\right)$ & $409.6 \pm 52.1$ & $404.8 \pm 55.8$ & 0.775 \\
\hline CV in cell size (\%) & $32.6 \pm 4.5$ & $34.6 \pm 2.6$ & 0.074 \\
\hline Hexagonality (\%) & $54.5 \pm 8.0$ & $54.2 \pm 9.5$ & 0.720 \\
\hline $\mathrm{CCT}(\mu \mathrm{m})$ & $514.9 \pm 32.3$ & $511.3 \pm 29.9$ & 0.917 \\
\hline
\end{tabular}

TABLE 4: Endothelial cell loss by decade of age.

\begin{tabular}{lcc}
\hline $\begin{array}{l}\text { Age group } \\
(\mathrm{yr})\end{array}$ & $\begin{array}{c}\text { Cell density }\left(\text { cell } / \mathrm{mm}^{2}\right) \\
(\text { mean } \pm \mathrm{SD})\end{array}$ & $\begin{array}{c}\text { Cell loss rate } \\
(\%)\end{array}$ \\
\hline $21-30$ & $2910.2 \pm 365.9$ & \\
$31-40$ & $2738.3 \pm 389.4$ & 5.9 \\
$41-50$ & $2682.0 \pm 286.7$ & 2.1 \\
$51-60$ & $2546.0 \pm 276.4$ & 5.1 \\
$61-70$ & $2497.6 \pm 331.7$ & 1.9 \\
\hline
\end{tabular}

Filipino eyes; they were higher than those in Indian, Thai, and Iranian eyes $[2,8-12]$. 
TABle 5: Comparison of endothelial cell density in Turkish, American, Japanese, Indian, Chinese, and Iranian eyes.

\begin{tabular}{|c|c|c|c|c|c|c|c|c|c|c|c|c|}
\hline \multirow[b]{2}{*}{$\begin{array}{l}\text { Age } \\
\text { group } \\
(y r)\end{array}$} & \multicolumn{2}{|c|}{ Turkish } & \multicolumn{2}{|c|}{ American [12] } & \multicolumn{2}{|c|}{ Japanese [12] } & \multicolumn{2}{|c|}{ Indian [8] } & \multicolumn{2}{|c|}{ Chinese [11] } & \multicolumn{2}{|c|}{ Iranian [10] } \\
\hline & $\begin{array}{c}\text { Number } \\
\text { of eyes }\end{array}$ & $\begin{array}{c}\text { Cell } \\
\text { density } \\
\left(\text { cell } / \mathrm{mm}^{2}\right) \\
(\text { mean } \pm \\
\text { SD })\end{array}$ & $\begin{array}{c}\text { Number } \\
\text { of eyes }\end{array}$ & $\begin{array}{c}\text { Cell } \\
\text { density } \\
\left(\text { cell } / \mathrm{mm}^{2}\right) \\
(\text { mean } \pm \\
\text { SD })\end{array}$ & $\begin{array}{c}\text { Number } \\
\text { of eyes }\end{array}$ & $\begin{array}{c}\text { Cell } \\
\text { density } \\
\left(\text { cell } / \mathrm{mm}^{2}\right) \\
(\text { mean } \pm \\
\text { SD })\end{array}$ & $\begin{array}{c}\text { Number } \\
\text { of eyes }\end{array}$ & $\begin{array}{c}\text { Cell } \\
\text { density } \\
\left(\text { cell } / \mathrm{mm}^{2}\right) \\
(\text { mean } \pm \\
\text { SD })\end{array}$ & $\begin{array}{c}\text { Number } \\
\text { of eyes }\end{array}$ & $\begin{array}{c}\text { Cell } \\
\text { density } \\
\left(\text { cell } / \mathrm{mm}^{2}\right) \\
(\text { mean } \pm \\
\text { SD })\end{array}$ & $\begin{array}{c}\text { Number } \\
\text { of eyes }\end{array}$ & $\begin{array}{c}\text { Cell } \\
\text { density } \\
\left(\text { cell } / \mathrm{mm}^{2}\right) \\
(\text { mean } \pm \\
\text { SD })\end{array}$ \\
\hline 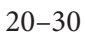 & & $2910 \pm 366$ & 11 & & 18 & $393 \pm 259$ & & & & $2988 \pm 243$ & 102 & $2407 \pm 399$ \\
\hline $1-40$ & 54 & ) & 6 & 8 & 10 & - & . & 34 & 100 & 20 & 45 & 49 \\
\hline $41-50$ & 58 & & 11 & & 11 & & 97 & 00 & 97 & 25 & 66 & 2071 \\
\hline $51-60$ & 56 & 6 & 13 & $5=$ & 10 & 3 & 98 & $38 \pm$ & 97 & 310 & 87 & $1939 \pm 344$ \\
\hline $61-70$ & 42 & $2498 \pm 332$ & 8 & $2684 \pm 384$ & 6 & $3307 \pm 330$ & 88 & $2431 \pm 357$ & 90 & $2739 \pm 316$ & 122 & $1775 \pm 348$ \\
\hline
\end{tabular}

We, however, noted a variation in the cell loss rate in different age groups with a higher loss of cells at the third and fifth decades. The reason for this increased rate of cell loss at these decades is not clear, and this may be related to an increased metabolic destruction of the endothelial cells with advancing age.

Matsuda et al. [12] found that the average corneal diameter in the American eyes was larger than that in the Japanese eyes. Regarding the differences seen in their data, Matsuda et al. [12] speculated that the larger corneal surface area in American eyes could be responsible for the lesser endothelial cell density when compared with Japanese eyes. Rao et al. [8] found that the average corneal diameter in their study in healthy Indian eyes was larger than that in the normal American and Japanese eyes and MCD was lower than that in the American and Japanese eyes. Once we did not measure the corneal diameter, we are unable to perform a similar analysis.

It has been reported that positive correlation between CCT and MCD is controversial $[8,14]$. Our results showed that the CCT tends to be thinner with age.

In conclusion, this study reports normative endothelial characteristics in a Turkish population that may serve as a useful baseline for future studies. This study has reported a consistent decrease in MCD and percentage of hexagonal cells, increase in MCA and CV in cell size with age. There was no statistically significant difference in endothelial cell charecteristics and CCT between genders. There was also no significant difference in these parameters between fellow eyes of subjects. Comparison with previous studies indicates that endothelial cell density in the Turkish eyes is less than that reported in the Japanese, American, Chinese, and Filipino eyes, However, the value for Turkish is higher than that reported in Indian, Thai, and Iranian eyes.

\section{Conflict of Interests}

The authors declare that there is no conflict of interests regarding the publication of this paper.

\section{Acknowledgment}

The authors would like to thank Associate Professor Dr. Gunay Can for his contribution to the research, particularly for the statistical analysis of the study.

\section{References}

[1] J. Mäkitie, A. Vannas, and M. Koskenvuo, "Corneal endothelial cells in mono- and di-zygotic twins," Investigative Ophthalmology and Visual Science, vol. 24, no. 8, pp. 1029-1032, 1983.

[2] N. Sopapornamorn, M. Lekskul, and S. Panichkul, "Corneal endothelial cell density and morphology in Phramongkutklao Hospital," Clinical Ophthalmology, vol. 2, no. 1, pp. 147-151, 2008.

[3] R. A. Laing, M. M. Sandstrom, A. R. Berrospi, and H. M. Leibowitz, "Changes in the corneal endothelium as a function of age," Experimental Eye Research, vol. 22, no. 6, pp. 587-594, 1976.

[4] W. M. Bourne, L. R. Nelson, and D. O. Hodge, "Continued endothelial cell loss ten years after lens implantation," Ophthalmology, vol. 101, no. 6, pp. 1014-1023, 1994.

[5] J. G. Slingsby and S. L. Forstot, "Effect of blunt trauma on the corneal endothelium," Archives of Ophthalmology, vol. 99, no. 6, pp. 1041-1043, 1981.

[6] I. Karai, S. Matsumura, S. Takise, S. Horiguchi, and M. Matsuda, "Morphological change in the corneal endothelium due to ultraviolet radiation in welders," British Journal of Ophthalmology, vol. 68, pp. 544-548, 1984.

[7] S. Mishima, "Clinical investigations on the corneal endothelium. XXXVIII Edward Jackson Memorial Lecture," American Journal of Ophthalmology, vol. 93, no. 1, pp. 1-29, 1982.

[8] S. K. Rao, P. R. Sen, R. Fogla, S. Gangadharan, P. Padmanabhan, and S. S. Badrinath, "Corneal endothelial cell density and morphology in normal Indian eyes," Cornea, vol. 19, no. 6, pp. 820$823,2000$.

[9] M. D. B. Padilla, S. A. B. Sibayan, and C. S. A. Gonzales, "Corneal endothelial cell density and morphology in normal Filipino eyes," Cornea, vol. 23, no. 2, pp. 129-135, 2004.

[10] M. N. Hashemian, S. Moghimi, M. A. Fard, M. R. Fallah, and M. R. Mansouri, "Corneal endothelial cell density and morphology in normal Iranian eyes," BMC Ophthalmology, vol. 6, article 9, 2006.

[11] S. Yunliang, H. Yuqiang, L. Ying-Peng, Z. Ming-Zhi, D. S. C. Lam, and S. K. Rao, "Corneal endothelial cell density and morphology in healthy Chinese eyes," Cornea, vol. 26, no. 2, pp. 130-132, 2007.

[12] M. Matsuda, R. W. Yee, and H. F. Edelhauser, "Comparison of the corneal endothelium in an American and a Japanese population," Archives of Ophthalmology, vol. 103, no. 1, pp. 68-70, 1985.

[13] A. Higa, H. Sakai, S. Sawaguchi et al., "Corneal endothelial cell density and associated factors in a population-based study in 
Japan: the Kumejima study," American Journal of Ophthalmology, vol. 149, no. 5, pp. 794-799, 2010.

[14] A. Müller, J. P. Craig, C. N. Grupcheva, and C. N. J. McGhee, "The effects of corned parameters on the assessment of endothelial cell density in the elderly eye," British Journal of Ophthalmology, vol. 88, no. 3, pp. 325-330, 2004. 


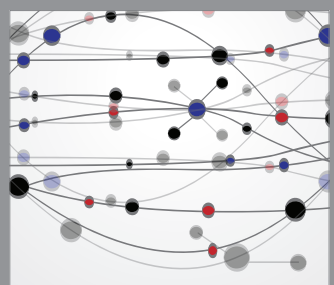

The Scientific World Journal
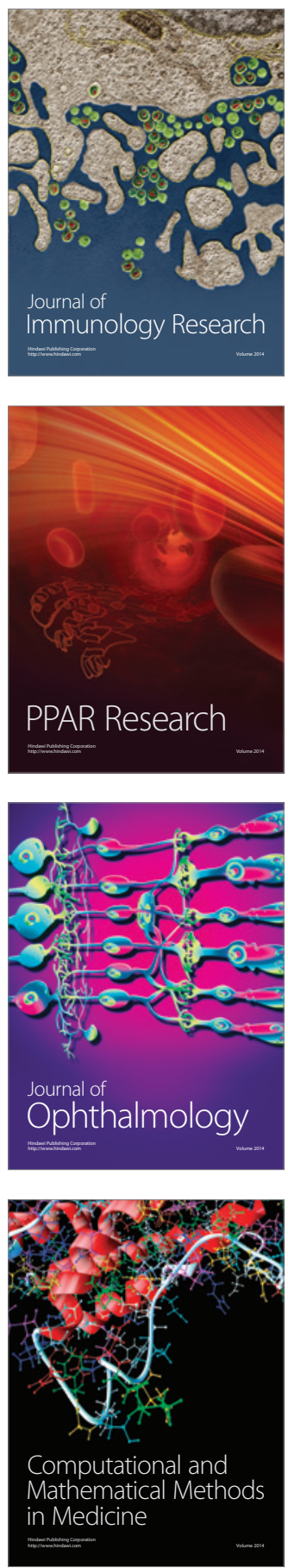

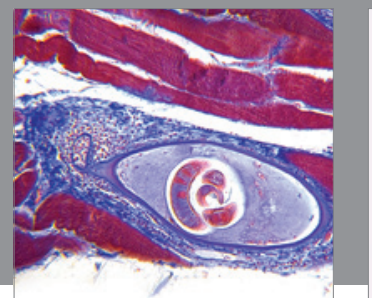

Gastroenterology

Research and Practice
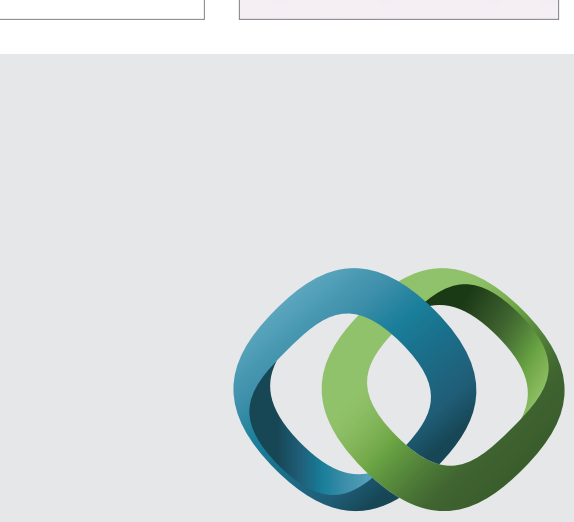

\section{Hindawi}

Submit your manuscripts at

http://www.hindawi.com
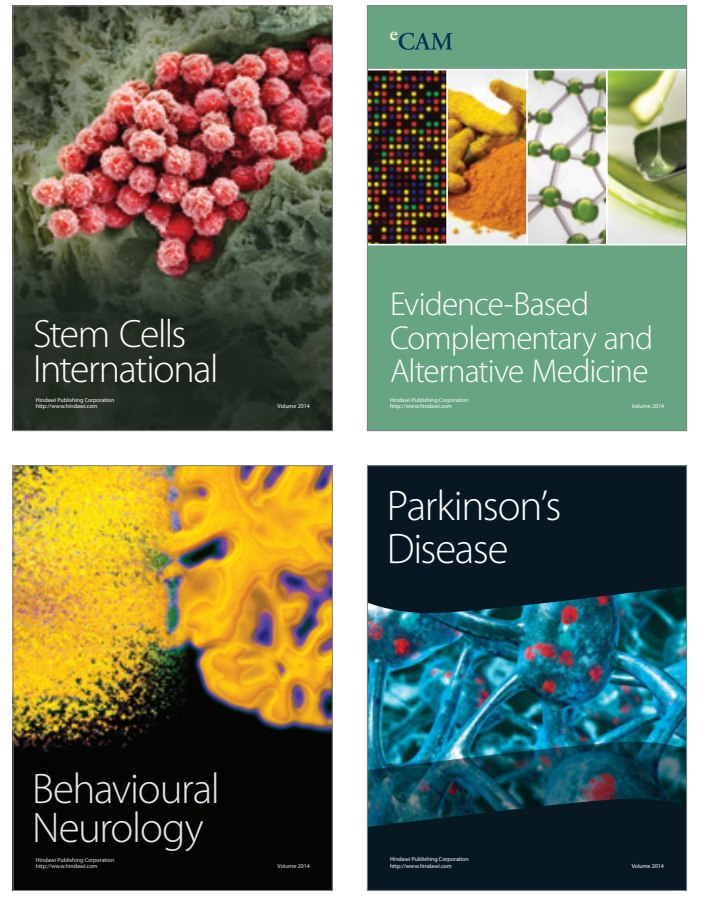
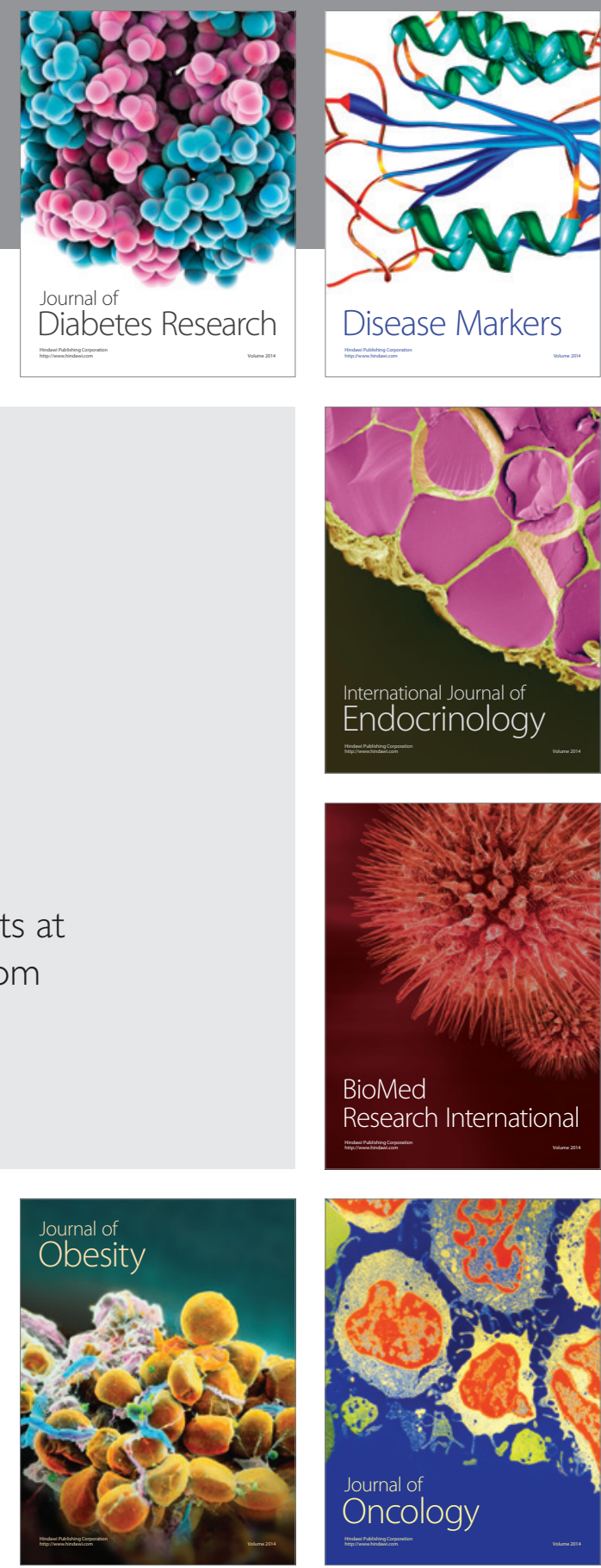

Disease Markers
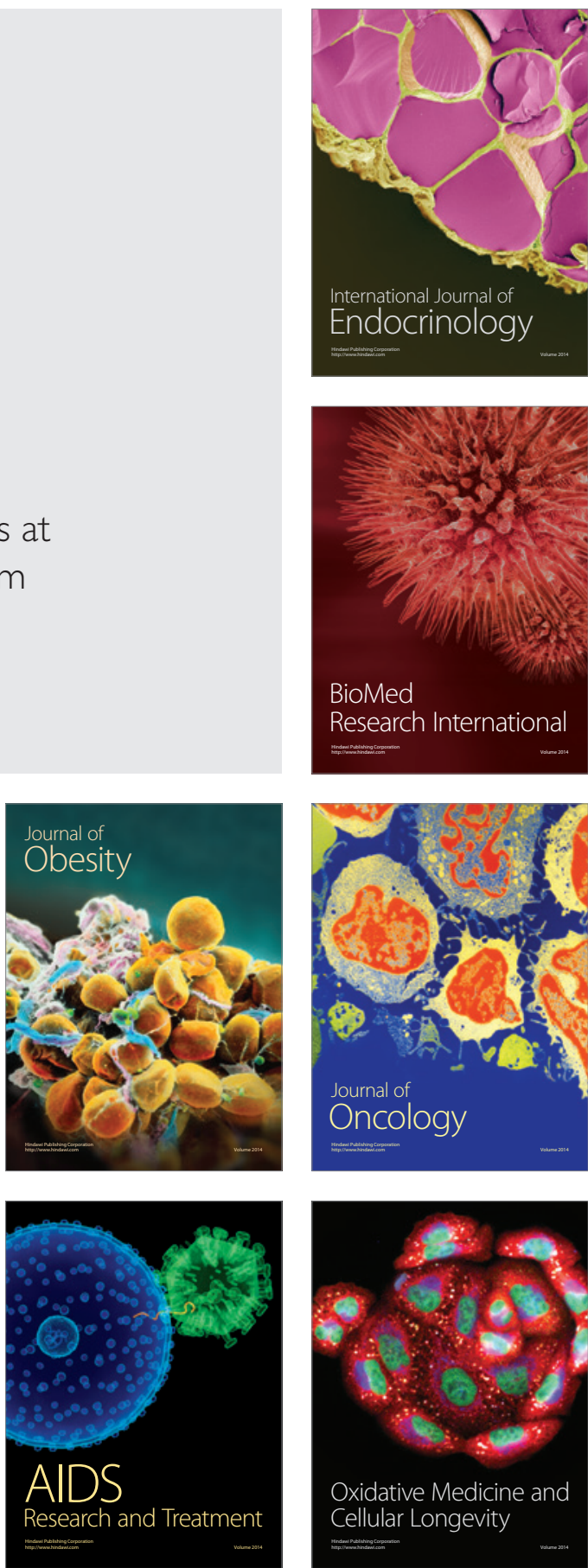